\title{
Effect of Composting on the Behavior of Polyolefin Films - A True-to-Life Experiment
}

\author{
Viktória Vargha ${ }^{1, *}$, Tamás Csoknyay ${ }^{1}$, Levente Kárpáti ${ }^{1}$, Gábor Bordós ${ }^{2}$, Mátyás Hartman ${ }^{3}$, \\ Judit Háhn', László Korecz, Györgyi Szarka ${ }^{4}$, Zsolt László ${ }^{5}$, Ottó Kelemen ${ }^{6}$ and \\ Sándor Szoboszlay ${ }^{2}$
}

${ }^{1}$ Department of Physical Chemistry and Materials Science, Budapest University of Technology and Economics, H-1111 Budapest, Müegyetem rkp.3, Hungary

${ }^{2}$ Department of Environmental Protection and Safety, Szent István University, H-2100 Gödöllö, Páter Károly u.1, Hungary

${ }^{3}$ Zöld Híd Régió Nonprofit Kft. H-2100 Gödöllö Dózsa Gy. út 69, Hungary

${ }^{4}$ Hungarian Academy of Sciences, Research Center of Natural Sciences, Institute of Materials- and Environmental Chemistry, H-1117 Budapest, Magyar tudósok körútja 2. H-1519 Budapest, Pf. 286, Hungary

${ }^{5}$ TVK, Member of the MOL group, TVK Development, Product- and Application Development, H-3581 Tiszaújváros Pf. 20, Hungary

${ }^{6}$ Qualchem Zrt., H-2072 Zsámbék Új Gyártelep, Hungary

\begin{abstract}
Commercial polypropylene (PP), high-, medium- and low density polyethylene (HDPE, MDPE, LDPE) films, as well as MDPE films containing pro-oxidative additives and thermoplastic starch (TPS) were composted for six weeks together with biologically degradable films, such as poly (lactic acid) (PLA), Ecovio (BASF), Mater Bi(Novamont) and cellophane. Visual appearance of the polyolefin-based films did not change significantly, while the biologically degradable films fell apart. Thickness and mechanical properties of the polyolefin-based films also did not vary significantly after composting. The thickness of the degradable films however increased due to biofilm formation and finally decreased due to biodegradation, and their mechanical properties drastically dropped. FTIR proved the formation of carbonyl absorption of commercial and of the additive-containing films respectively) after composting due to oxidation. The FTIR-spectrum of the biodegradable films showed drastic change after composting. Formation of free radicals was detectable by ESR-spectroscopy, if pro-oxidative additive containing MDPE film was exposed for one week to sunlight, and the intensity of free radical formation increased after composting. The number-average molecular mass of MDPE films containing pro-oxidative additives decreased, low molecular mass fractions appeared and polydispersity increased after composting. Commercial polyolefin films were covered by microorganisms much more densly than films containing pro-oxidative additives detected by SEM. Even TPS did not increase the quantity of microorganisms. Biodegradable films were densly covered by microorganisms of different types and they became porous and holes were observable on their surface. It can be concluded that composting had no significant effect on the behaviour of the commercial PP and PE films. Signs of initial degradation were observable on MDPE films with pro-oxidative additives and TPS after 6 weeks composting, although it cannot be considered as biological degradation. Non of the tested polyolefin films suffered such degree of degradation in compost, as the biologically degradable films. It may be concluded that polyolefin films neither degrade in compost nor they undergo biodegradation.
\end{abstract}

Keywords: Polyolefin films, degradation in compost, material testing.

\section{INTRODUCTION}

Polyolefins (PE, PP) comprise about $48 \%$ of plastics production, and about $40 \%$ of the produced plastics is used for packaging [1]. This is a serious environmental problem. In Europe the tendency is to reduce landfill disposal of plastics waste possibly to zero favouring plastics recycling and energy recovery. Some countries in Europe have almoust accomplished this, the majority of plastics waste however is still disposed to landfill. Throughout Europe in 2012 26,3\% of post-consumer plastics waste is recycled, $35,6 \%$ is

${ }^{*}$ Correspondence Address to this author at the Department of Physical Chemistry and Materials Science, Budapest University of Technology and Economics, $\mathrm{H}-1111$ Budapest, Müegyetem rkp.3, Hungary;

Tel: +36204771828; E-mail: vvargha@mail.bme.hu used for energy recovery, and $38,1 \%$ goes to landfill disposal. The decreasing oil prices further encourage polyolefin manufacturers to increase their production. Therefore it remains still an essential problem, what happens with polyolefin waste after disposal. A great number of references deal with polyethylene and polypropylene degradation.

A systematic study of polyethylene degradation mechanism was carried out by Albertsson et al. [2-8]. Koutny et al. give an extensive literature survey on polyethylene degradation [9]. A comprehensive review is given on the biological degradation of plastics generally by Shah et al. [10]. Lucas et al. review the mechanisms and estimation techniques of polymer biodegradation [11]. Eubeler and co-workers 
summarize the test methodologies and procedures of environmental biodegradation of synthetic polymers [12]. The same author and co-authors report on the environmental biodegradation of synthetic polymers and on the biodegradation of different polymer groups [13]. The use of polyethylene film is especially widespread in agriculture. According to Kyrikou and Briassoulis in their review paper attempt to delineate the definition of degradability of polymers used in agriculture explaining that many polymers that are claimed to be 'biodegradable' are in fact 'bioerodable', 'hydrobiodegradable', 'photodegradable', controlled degradable or just partially biodegradable [14]. In this review paper emphasis is placed on the controversial issues regarding biodegradability of some of these polymers. Feuilloley et al. studied the biodegradation of three different commercial polyethylene mulch films [15]. They have found very low degree of biodegradation of the commercial PE films. Fontanella and co-authors studied the biodegradability of high density polyethylene films (HDPE), low density polyethylene films (LDPE) and linear low density polyethylene films (LLDPE) with a balanced content of antioxidants and pro-oxidants [16]. After pretreatment the oxidized samples were then inoculated with the strain Rhodococcus rhodochrous in mineral medium, and incubated up to 180 days. Rhodococcus cells were able to remain metabolically active on at least six types of PE films containing pro-oxidants during 180 days, suggesting that they gain energy from the material, hence from an ongoing biodegradation. The nature of PE matrix is important but the most important parameters are the nature, the composition and the concentration of the metals present in the complexes used as prooxidants. The authors affirm that these results allow to progress in the understanding and possibly the applications of the processes put into evidence. The combination of appropriate PE matrices and prooxidants could lead to the manufacture biodegradable products for some applications, it should be known however that this biodegradation will be at a slow rate, in particular when compared with the much faster rate of fragmentation caused by polymer oxidation. Synergistic effects of sunlight exposure, thermal aging and fungal biodegradation on the oxidation and biodegradation of linear low-density polyethylene (PE-LLD) films containing pro-oxidant additives were examined by Corti [17]. It was concluded that the degradation of oxo-biodegradable PE-LLD is enhanced by the synergistic action of both abiotic and biological factors after its initial oxidation by exposure to direct sunlight. Soni and co-workers developed a bacterial consortium for the biodegradation of porous and non-porous LDPE [18]. Biodegradation studies revealed that the consortium was capable of degrading the porous form of LDPE easily. This is due to better bacterial colonization and increased activity in the voids of the polymer. Based on these findings a consortium is proposed for use in plastic-waste management strategies. Siracusa offer a complete view of the state of the art on biodegradable polymer packages for food application [19]. The biodegradability of $\mathrm{PE} /$ starch blends was investigated by a great number of authors [20-29]. Abd El Rehim investigated LDPE/starch/PEG4000 blends in the form of sheets prepared in roll-mill [29]. The starch content increased from 5 to $25 \mathrm{wt} \%$ by $5 \mathrm{wt} \%$. They concluded that synergistic effect of combining UV-sunlight and soil burial treatments resulted dramatic changes in degradation, especially at 25 wt \% starch content. They suppose biodegradation of LDPE/starch blend and suggest for production of disposal and packaging plastic products one of bio-degradable plastic. There arise two questions. Will it be possible to blow film at such a high starch content? Microbial investigations were not carried out in order to prove biodegradation. Ojeda [30] believe in an increase in the biodegradation rate of polyethylenes, HDPE and LLDPE plastic bags by the addition of pro-oxidant additives. These packaging materials were exposed to natural weathering and periodically analyzed with respect to changes in mechanical and structural properties. After a year of exposure, residual samples of the bags were incubated in substrates (compost of urban solid waste, perlite and soil) at $58{ }^{\circ} \mathrm{C}$ and at $50 \%$ humidity. The biodegradation of the materials was estimated by their mineralization to $\mathrm{CO}_{2}$. The molar mass of the prooxidant-activated PE decreased and oxygen incorporation into the chains increased significantly during natural weathering. These samples showed a mineralization level of $12.4 \%$ after three months of incubation with compost. Higher extents of mineralization were obtained for saturated humidity than for natural humidity. The growth of fungi of the genera Aspergillus and Penicillium was observed on PE films containing pro-oxidant additives exposed to natural weathering for one year or longer. Conventional PE films exposed to natural weathering showed small biodegradation. Chiellini investigated the biodegradation of LDPE containing pro-oxidant additives in soil and mature compost [31]. Pro-oxidant additives proved to be effective in promoting the oxidation and subsequent biodegradation of polyethylene in soil environments. Control of rate and 
completeness of biodegradation, and cumulative time for oxidation and biodegradation under different environmental conditions remain still to be solved. Matsunaga and Whitney studied the effect of surface treatment of LDPE by corona discharge and UV irradiation on the initial colonization and possible subsequent biodegradation period [32]. It was confirmed that the corona discharge treatment and the UV exposure did increase the surface energy and oxidize the surface of LDPE flm. Enrichment of microbial colonization was confirmed for both treatments. It seems that the corona discharge treatment was markedly more effective and more practical than UV exposure. Further studies are needed to determine if the accelerated colonisation has a significant effect in the overall rate of degradation. Kaur, Gupta and Kumari modified the surface of polyethylene with irradiation grafting with hydrophilic monomers such as methacrylic acid and acrylamide [33]. Grafting improved the thermal and swelling behaviors of PE enabling it to be utilized as a membrane in ion separation studies particularly for desalination processes. The property of biodegradation imparted to the film upon grafting is additional and can be used as an environment friendly polymer.

From our literature study on the degradation of polyolefins including polyethylene there are many contradictory results. Pre-treatment of any kind of polyolefin films before composting is not life-like. After use of packaging materials they land in the garbage and will be deposited or composted [34]. According to our experiments polyethylene films in soil did not undergo significant change and definitely not biodegraded [35]. Our aim was to carry out a true-to-life experiment on polyolefin films and to reveal their behaviour in compost.

\section{EXPERIMENTAL}

\section{Materials}

All types of polyethylene and also polypropylene were made by TVK, but TVK insisted on not revealing the grade of their products. That is why we could only give the names low-density PE, medium density PE Phillips type, and PP. All types of polyolefins were available in the form of granules. Since we used Phillips type medium density PE for compounding with pro-oxydants and TPS, films of commercial PE and the additive-containing PE were blown together at the same place, namely at Plastics Processing Plant Tázlár Hungary. Since we did not plan to add any additives to PPand LDPE, we did not blow film from these, only 100 $\times 100 \times 0.3 \mathrm{~mm}$ plates were pressed. The polyolefin films tested in compost are summarized in Table 1. Composting was carried out at Zöld Híd Régió Kft. Gödöllő Hungary. Composting conditions include continous aeration, a temperature of $80^{\circ} \mathrm{C}$ and lasted for 6 weeks. No samples were taken during composting, only after 6 weeks, since this period is considered generally acceptable.

Table 1: Films Tested in Compost

\begin{tabular}{|c|c|}
\hline Abbreviation & Description \\
\hline PP & commercial polypropylene (TVK) \\
\hline LDPE & commercial low-density polyethylene (TVK) \\
\hline MDPE & commercial medium-density polyethylene Phillips type (TVK) \\
\hline HDPE & commercial high-density polyethylene Phillips-type (TVK) \\
\hline Zöld híd & commercial medium-density polyethylene containing pro-oxidant (Qualchem Zrt.) \\
\hline PE 238 & $\begin{array}{l}\text { commercial medium-density polyethylene containing pro-oxidant (Fe 0,072 \%, Co 0,015\%, Zr 0,031\%, } \\
\qquad \text { Mn 0,006 \%, total metal content 0,124\%) (Qualchem + BME) }\end{array}$ \\
\hline PE 242 & $\begin{array}{l}\text { commercial middle-density polyethylene containing pro-oxidant (Fe 0,051\%, Co 0,025\%, Zr 0,024\%, } \\
\qquad \text { Mn } 0,044 \% \text { - total metal content } 0,144 \% \text { (Qualchem + BME) }\end{array}$ \\
\hline PE 264 & $\begin{array}{c}\text { commercial middle-density polyethylene containing pro-oxidant }(0.0576 \% \mathrm{Fe}, 0.0284 \% \mathrm{Co}, 0.0192 \% \mathrm{Zr}, 0.002 \% \\
\text { Mn total metal content } 0.107 \% \text { and } 8.75 \% \text { thermoplastic starch) (Qualchem + BME) }\end{array}$ \\
\hline PE 297 & $\begin{array}{c}\text { commercial middle-density polyethylene containing pro-oxidant (Mn 0,0103\%, Co 0,0094 \%, total metal content } \\
0,0197 \% \text { ) and } 8.75 \% \text { thermoplastic starch) (Qualchem + BME) }\end{array}$ \\
\hline BASF & polyester + polylactic acid blend (Ecovio - BASF) \\
\hline Mater $\mathrm{Bi}$ & Bioplastic based on starch and biodegradable polyesters (Novamont) \\
\hline Celofán & Cellophane film \\
\hline
\end{tabular}




\section{METHODS}

The films were tested before and after composting visually and compared. Thickness was measured by micrometer. For testing mechanical properties an Instron5566 was used with $5 \mathrm{~N}$ and $100 \mathrm{~mm} / \mathrm{min}$ crosshead speed. Five parallel measurements have been done on dumbbell-shaped samples. Tensile strength and elongation at break were measured. Structure was tested by FTIR-spectroscopy using a Bruker Tensor 27 in transmission mode. For detecting radicals after composting ESR-spectroscopy Bruker Elexsys 500 spectrometer was used. Specimen were introduced into ESR pipes, measurements took place at room temperature. For molecular mass measurements GPC Malvern Viscotek 350 HT-GPC with 2 Phenogel 10u Linear(2) coloumn was used at
$160{ }^{\circ} \mathrm{C}$ in $1,2,4-$ trichlorobenzene solution. Morphology was evaluated by scanning electron microscopy (SEM Jeol JSM 6380LA electron microscop). Before testing the surface of the samples were covered with $\mathrm{Pd}-\mathrm{Ag}$ alloy. Images of 250x, 500x, 1000x, 2500x and 5000x magnification were made.

\section{RESULTS}

Visual appearance did not significantly change after composting, the biodegradable films however fell apart. Some parts of Cellophane could be collected for further investigation. The change of thickness of the films is represented in Figure 1. It must be noted that PP and LDPE were tested in the form of plates not film, this is the reason of the higher thickness.

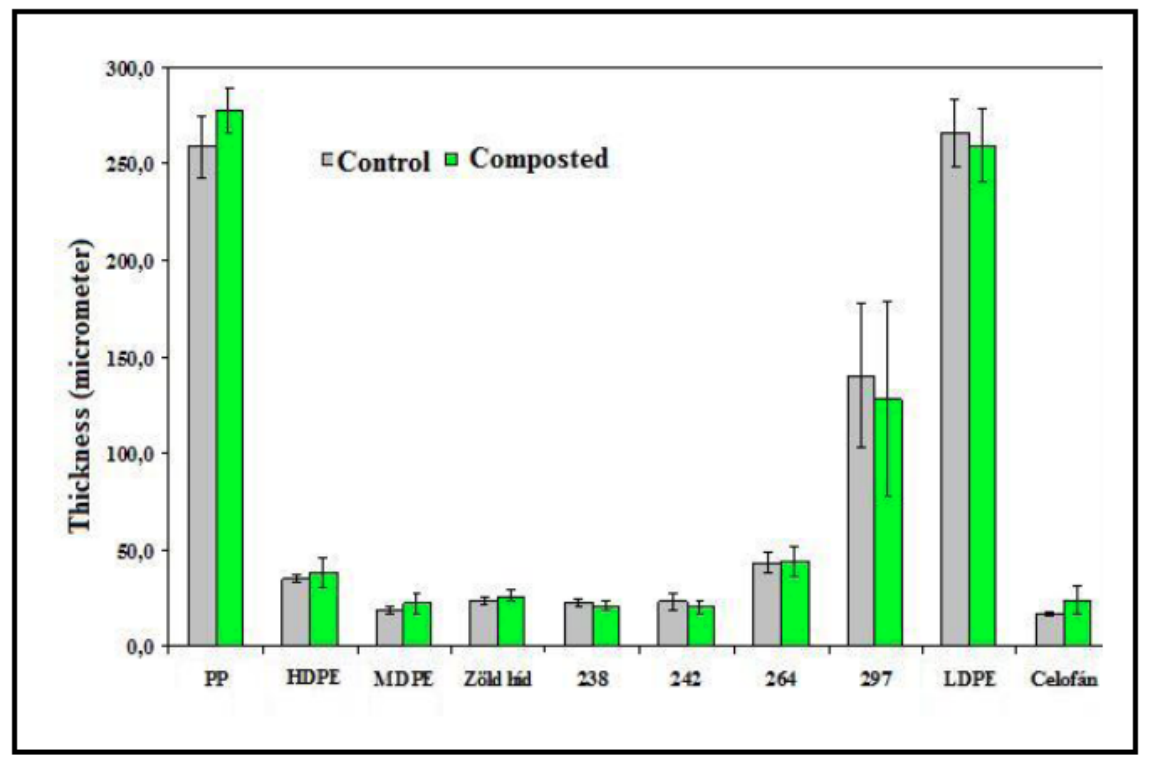

Figure 1: Thickness of the tested films before and after composting.



Figure 2: Tensile strength of the tested films before and after composting. 


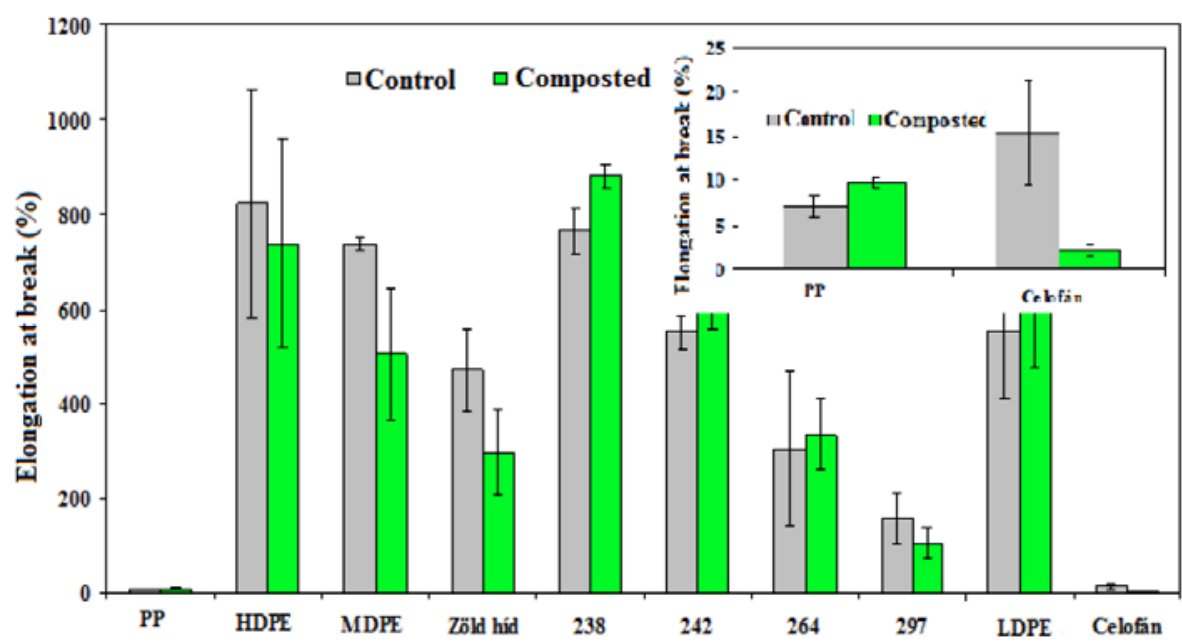

Figure 3: Elongation at break of the tested films before and after composting.

Decrease in thickness is expected due to biodegradation, increase due to biofilm formation. Significant increase in film thickness was observable only on Cellophane film. The change in tensile strength before and after composting is represented in Figure 2.

For polyolefin films both increase and decrease in tensile strength were observed, although scatterings mostly overlap the changes. It may be concluded that significant decrease could be detected only for the commercial MDPE film and the biodegradable cellophane film. Increase in tensile strength may be due to cross-linking as a result of initial degradation. Elongation at break is shown in Figure 3.

Elongation at break did not change significantly for polyolefin films, it drastically decreased however for the biodegradable ones. It may be concluded, that only the biodegradable films have been mechanically detered in the compost.

Results of FTIR-spectroscopy on te example of PP are presented by Figure 4.

FTIR-spectra showed the same results for all the polyolefin samples. Since the compost was airated for 6 weeks oxidation was unavoidable, meaning the increase in oxo-group absorption in polyolefin films after composting due to oxidation. Other structural changes were not detectable. Degradable films however showed drastical changes in structure after composting. As demonstrated by the FTIR-spectrum of Ecovio film, increase in OH-group absorption, appearance of $\mathrm{CH}$-branches, formation of new ester

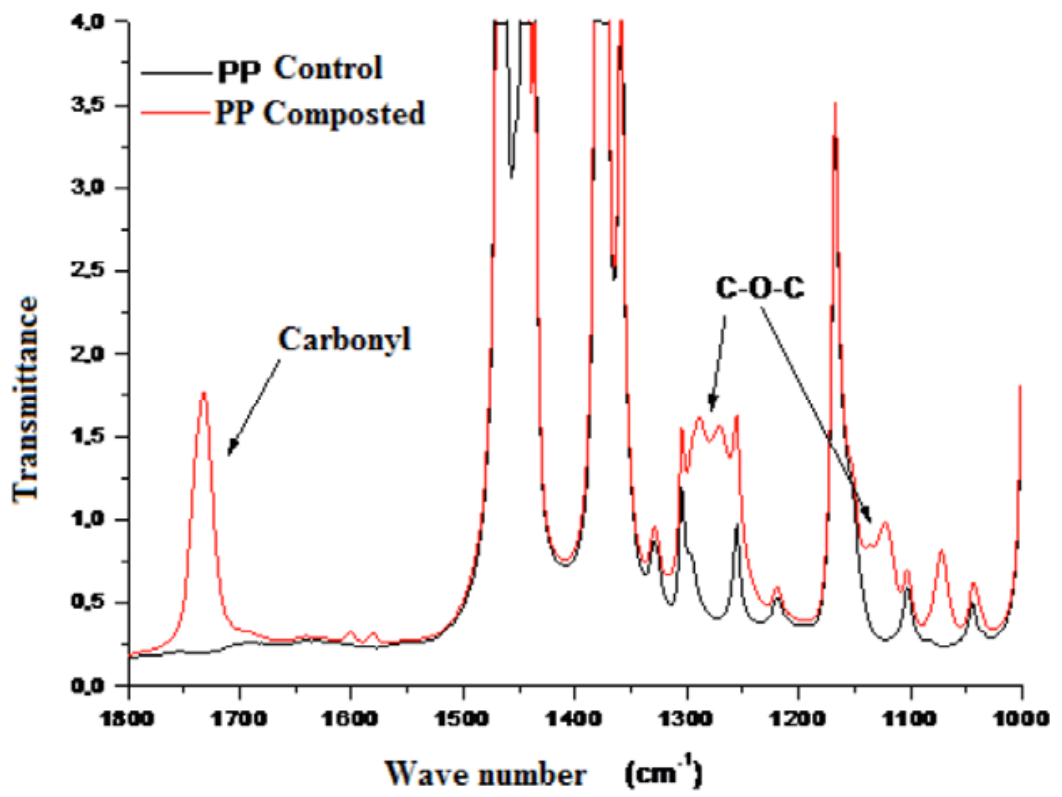

Figure 4: FTIR spectrum of PP plates before and after composting. 


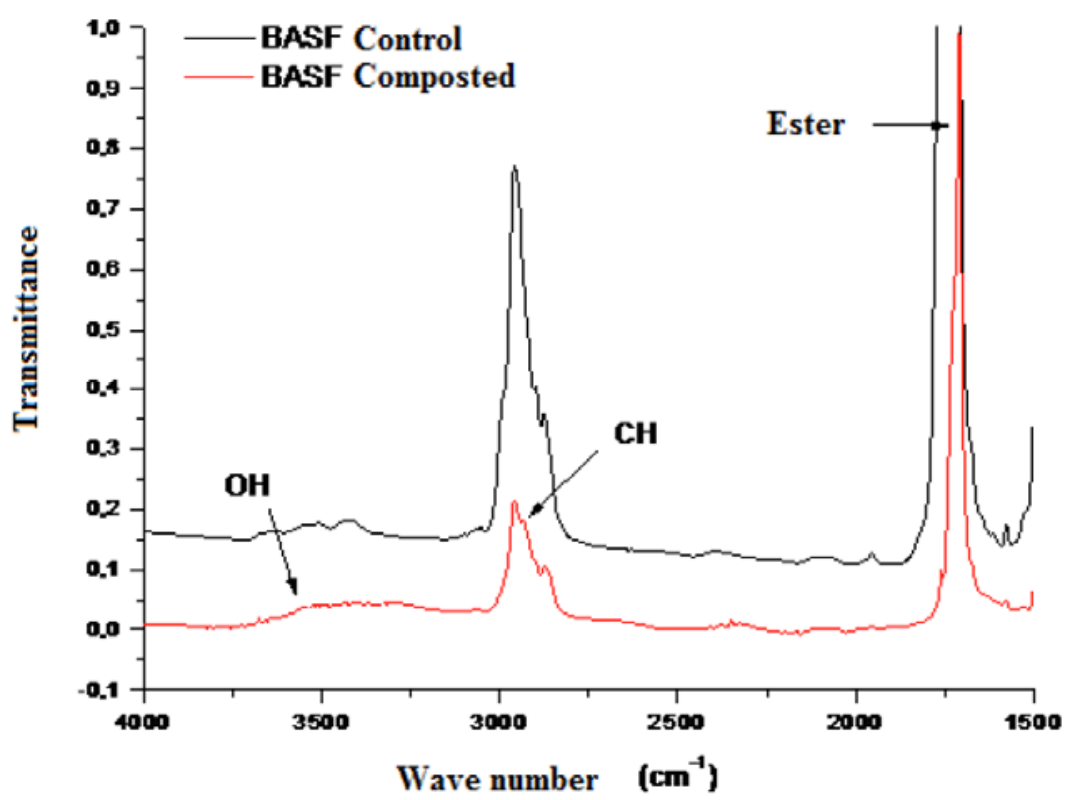

Figure 5: FTIR spectrum of BASF film before and after composting.

groups supported by multiplication and shifting of ester carbonyl groups were detectable (Figure 5).

ESR-spectra of degradable films always indicated the appearance of free radicals after composting. Commercial MDPE film containing pro-oxidative additives (Zöld híd) was exposed to sunlight for one week, then composted. Free radicals could be detected in Zöld híd film after exposing to sunlight, and concentration of free radicals further increased after composting (Figure 6). Presence of free radicals were not detected after composting in polyolefin films without exposure to sunlight. This was only a qualitative test to have an idea of radical formation after exposure to sunlight and after composting. According to Eubeler degradation of polyolefins may be enhanced partly after ultraviolet (UV) irradiation in an accelerated weathering chamber [13]. This and also the works of Corti [17] support our findings. It would also be important to compare the effect of radiation exposure in samples with and without pro-oxidants. This may be subject of an other experiment.

Change in number-average molecular mass and polydispersity of the tested polyolefin films are shown by Figures 7-8.

ESR-spectrum of Zöld híd film

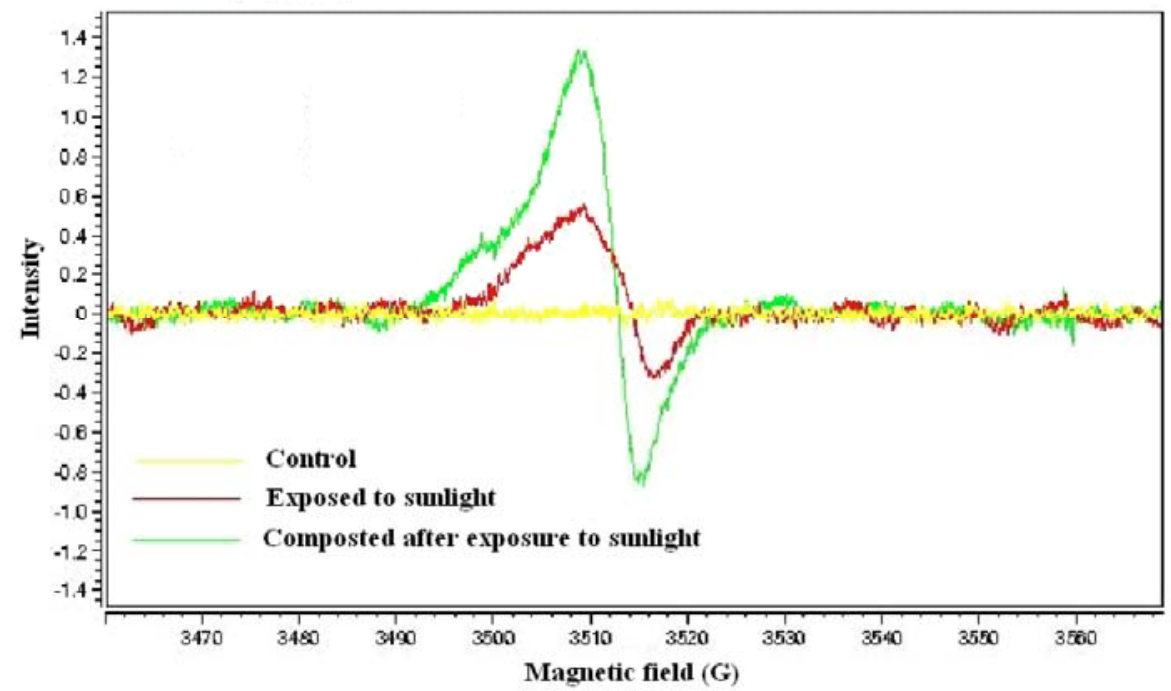

Figure 6: ESR spectrum of Zöld híd film (MDPE with pro-oxidant) after exposure to sunlight and after composting. 


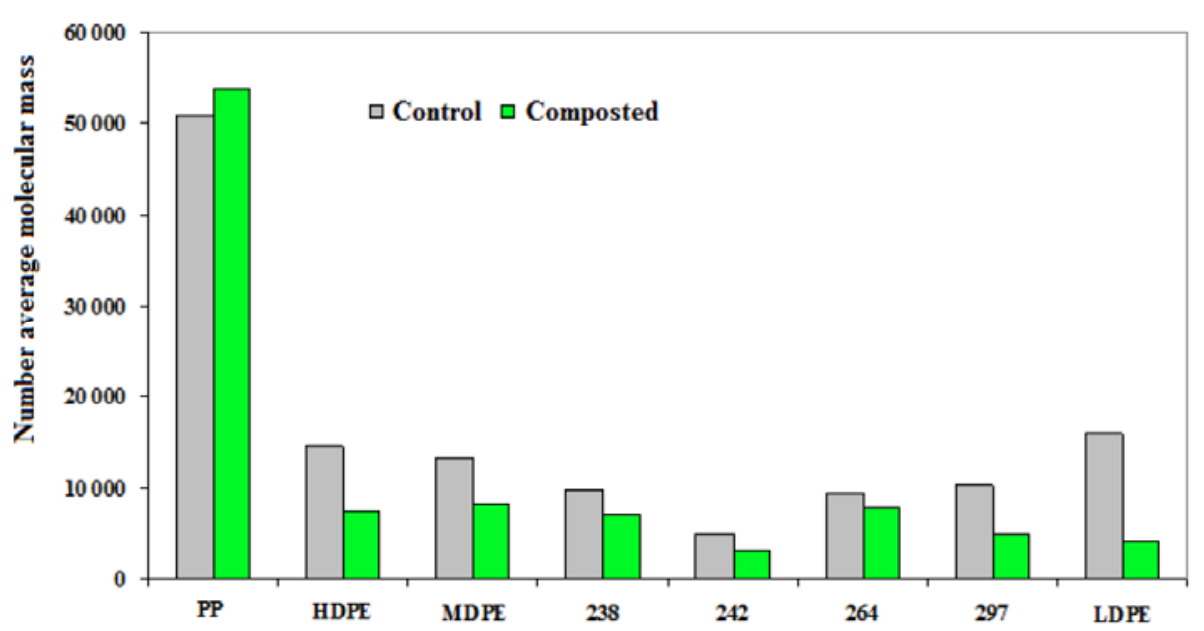

Figure 7: Change in number-average molecular mass of the tested polyolefin films before and after composting.

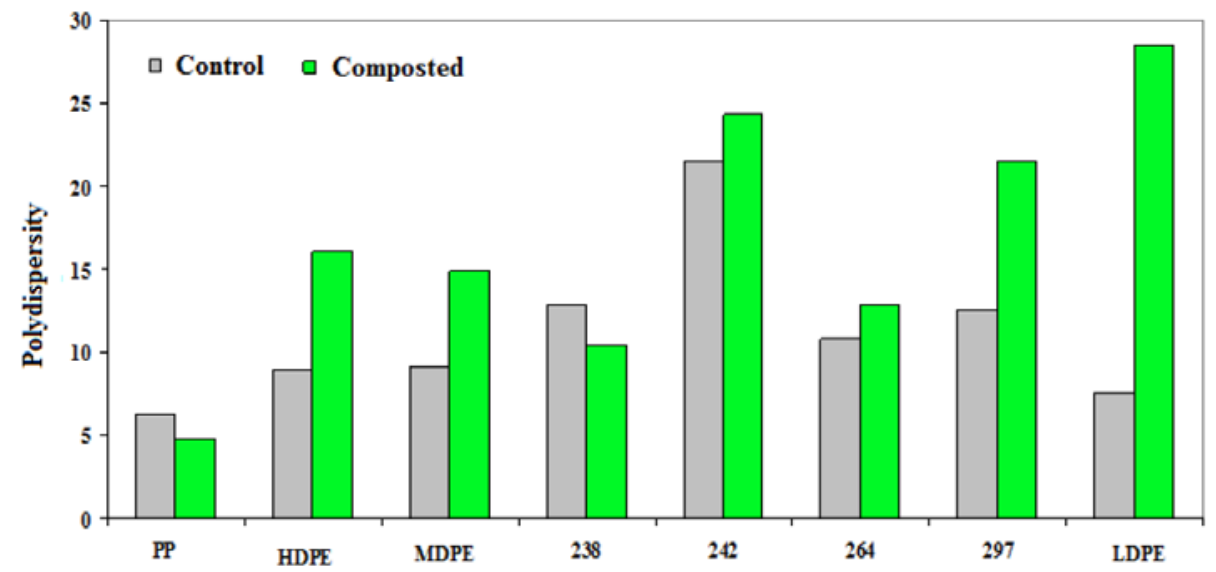

Figure 8: Change in polydispersity of the tested polyolefin films before and after composting.

All polyolefin films showed slight decrease in number-average molecular mass, which may refer to some degradation of small extent, although not significant. Noteworthy is however the great diversity of polydispersity of the polyolefin films. The biodegradable films disappeared in the compost, only some peaces of cellophane film could be collected for testing.

The results of SEM can be seen in Figure $\mathbf{9}$.

Commercial polypropylene is isotactic and semicrystalline. Crystallization occured during composting, however microorganisms could not be detected on PP surface. LDPE did not crystallize during composting, although no microorganism appeared on its surface. It is noteworthy that a great coverage of microorganisms appeared on the surface of MDPE after composting. In case of HDPE composting resulted only a few microorganism on the surface. The prooxidant containing MDPE namely Zöld híd film had fewer microorganism on its surface than the commercial MDPE film. The pro-oxidant containing
MDPE films PE238 and PE242 behave similarly to Zöld Híd film, practically no microorganism settled on their surface after composting. The pro-oxidant and TPS containing MDPE films PE264 and PE297 were more suscaptable to the settlement of microorganism during composting than the films without TPS. The surface of the biodegradable films, BASF, Mater $\mathrm{Bi}$, Cellophane and PLA are fully covered with microorganisms of different types and threads of fungi formed in compost. Based on the results of SEM it may be concluded that commercial PP, LDPE and HDPE have no affinity for microorganisms in compost. This is in accordance with Feuilloley [15]. Surprisingly commercial MDPE was susceptible for microbial attack during composting. Prooxidant containing MDPE was less susceptible for microorganisms as though pro-oxidant would repel microbes. Even the presence of thermoplastic starch did not attract more microbes in the compost, that means that the TPS containing films had less microorganisms on their surface than the commercial polyethylene MDPE. 


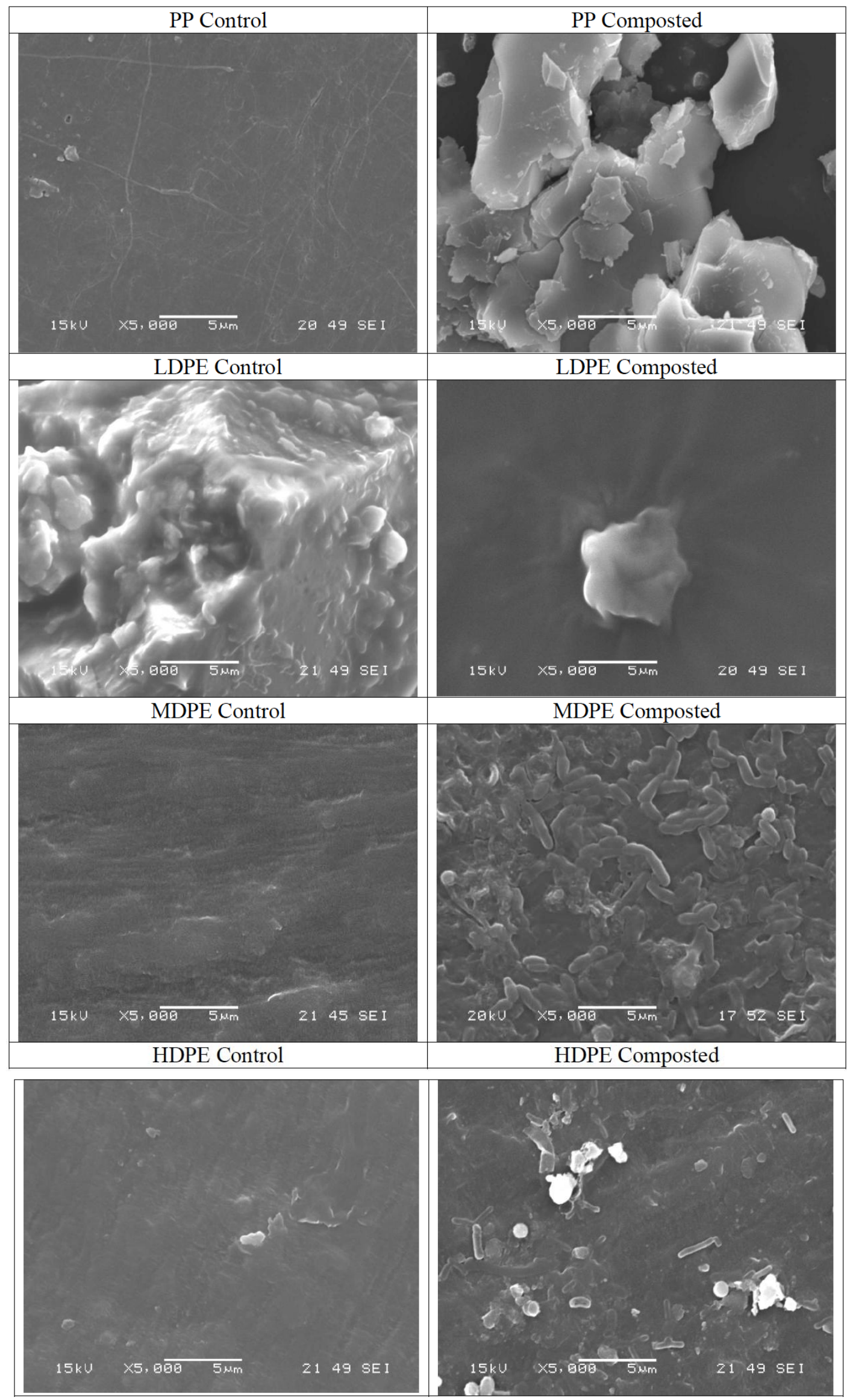


(Figure 9). Continued.
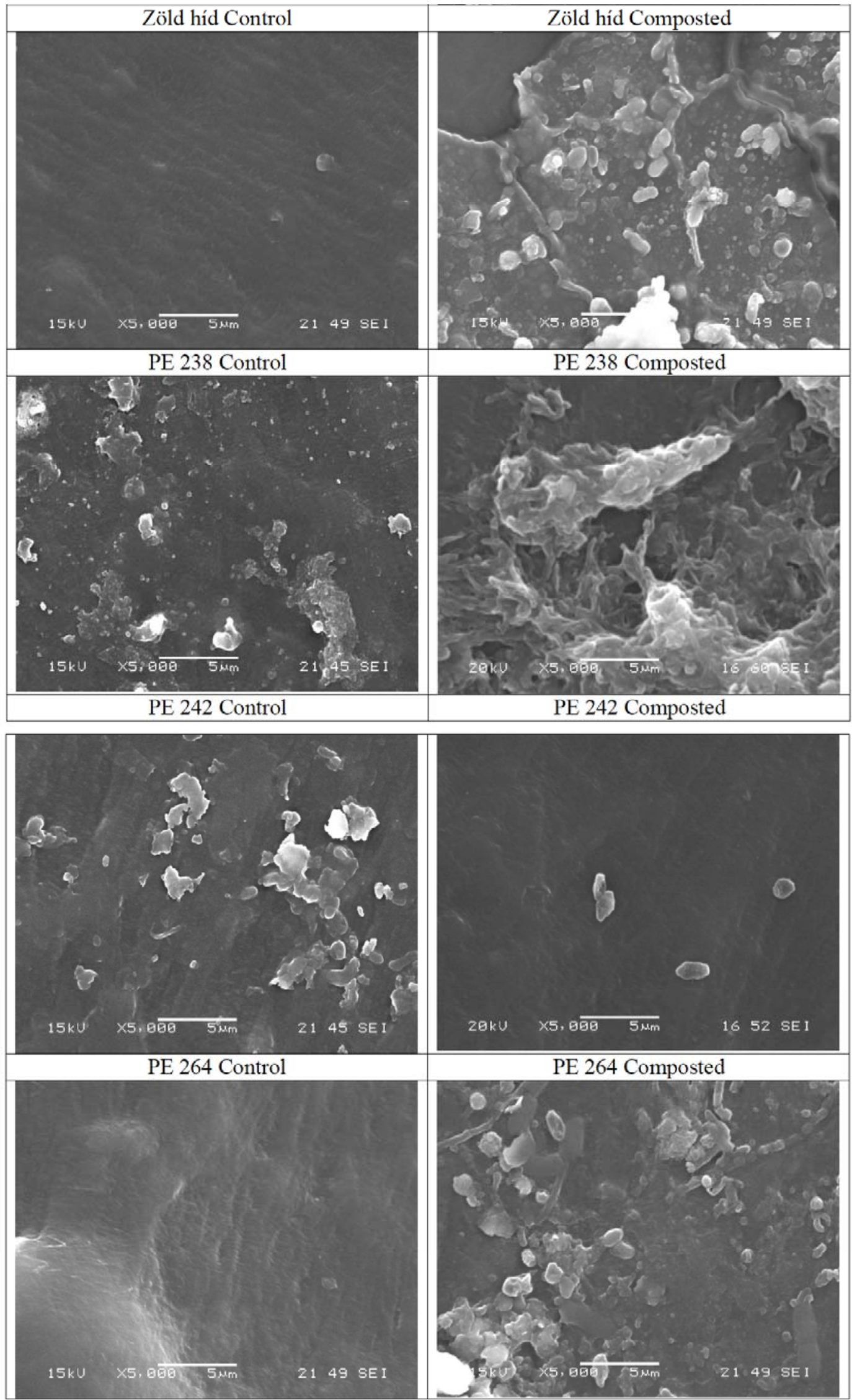
(Figure 9). Continued.
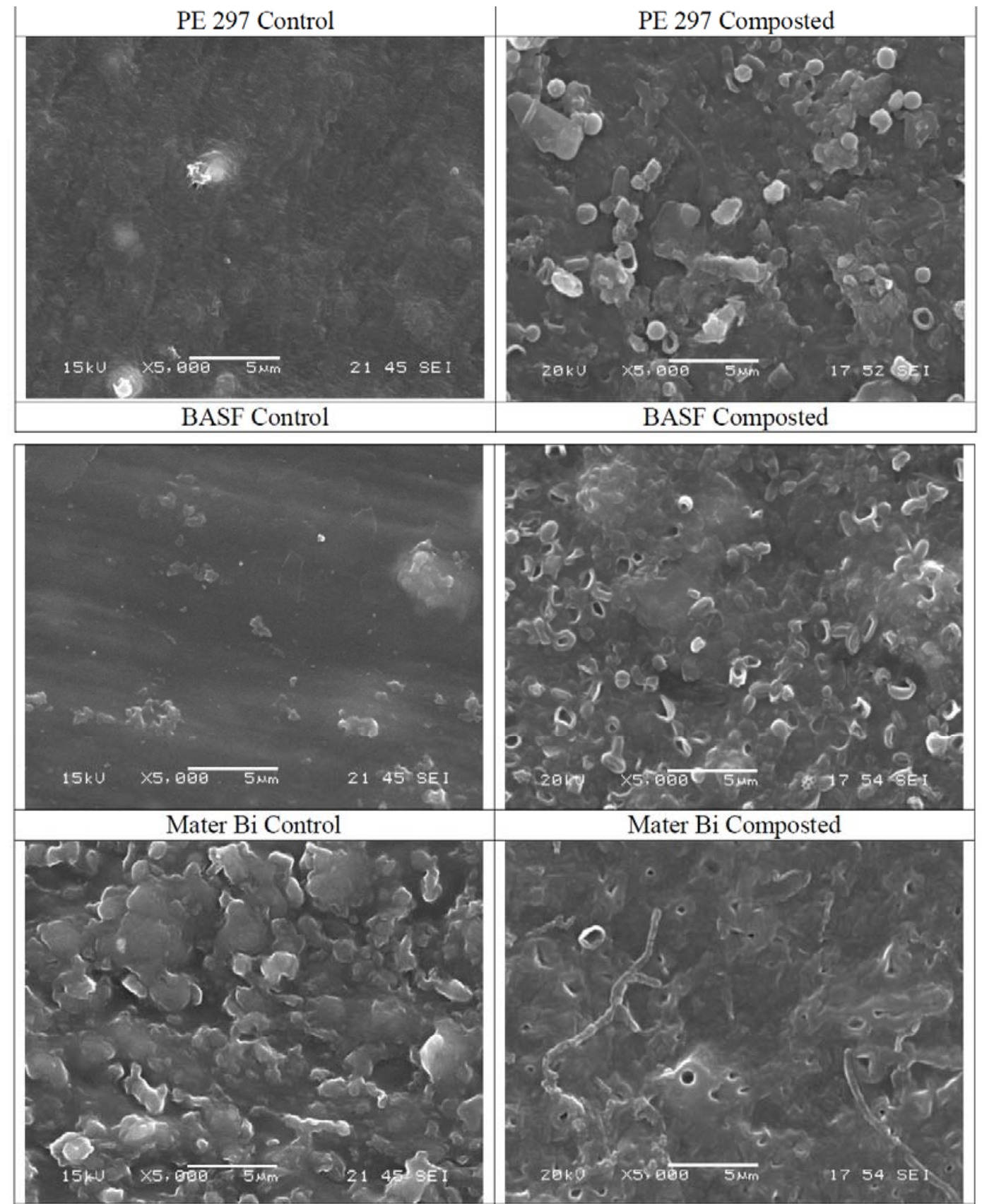

Celofán Control
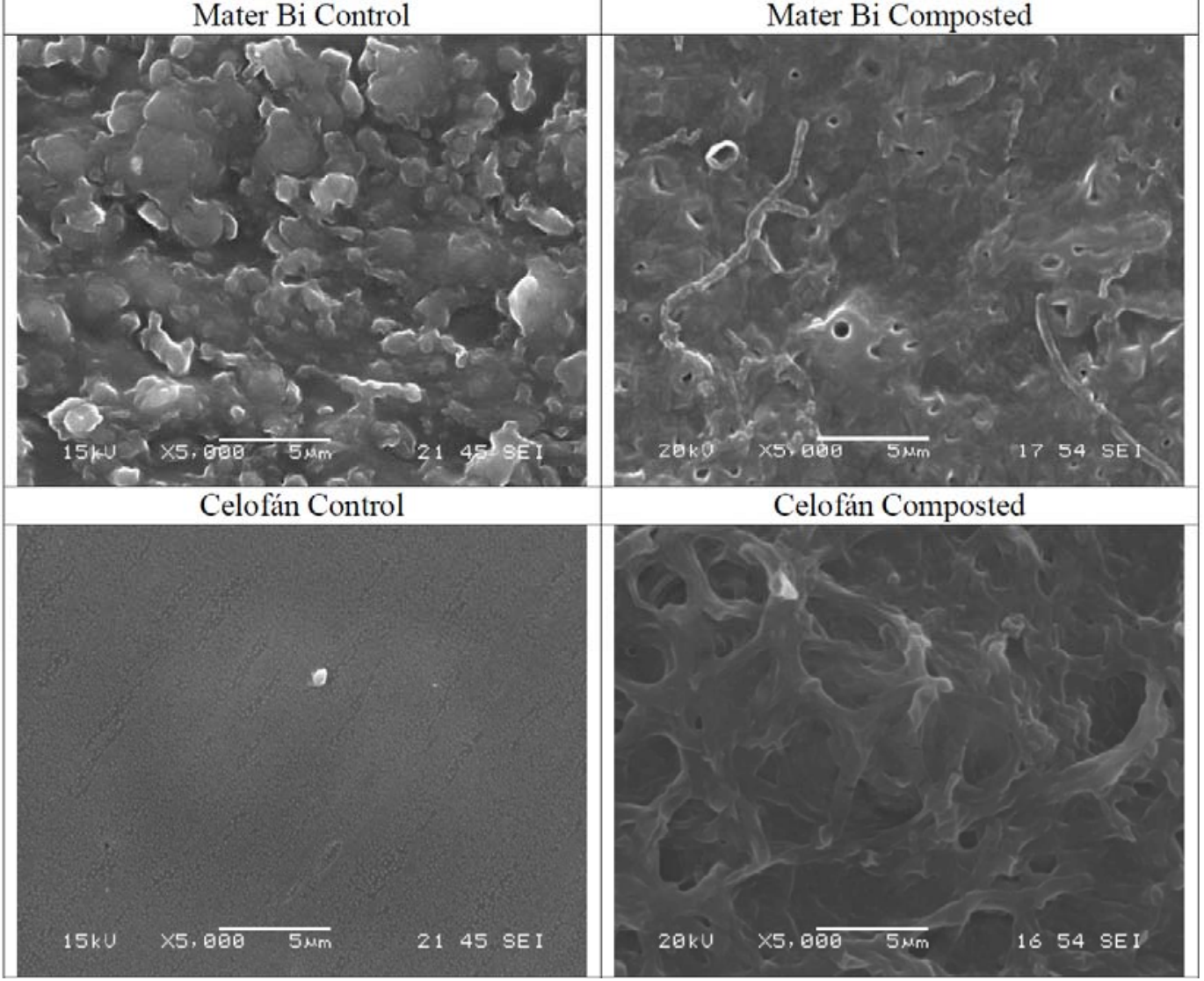
(Figure 9). Continued.

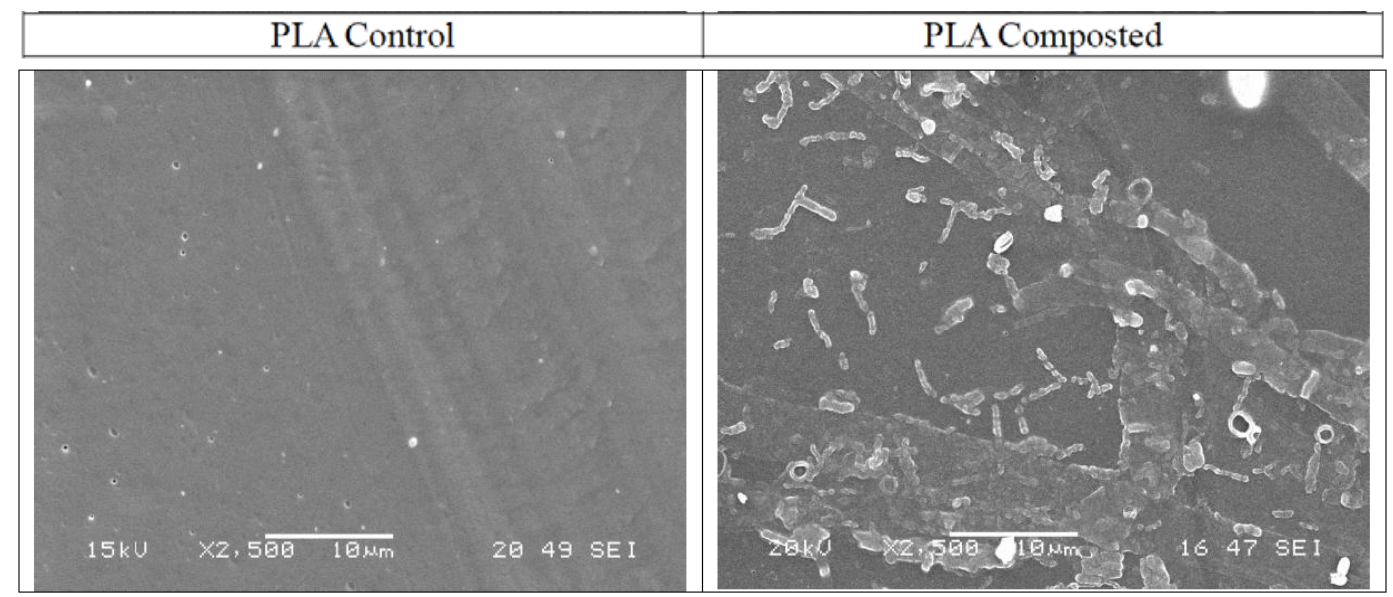

Figure 9: Scanning electron microscopic images of the tested films before and after composting.

\section{CONCLUSIONS}

Yearly production of plastics is contnouisly increasing resulting in a drastic growing of plastics waste. Reducing plastics waste includes moderation of production, proper waste management and developing environmentally or biologically degradable plastics. Aim of this work was a true-to-life experiment on the behaviour of polyolefin based films in compost. Composting was carried out at Zöld Híd Régió Kft. Gödöllö Hungary. The investigated samples were commercial PP and LDPE plates, commercial MDPE, HDPE films, MDPE films with pro-oxidants and thermoplastic starch. Biologically degradable films, such as Ecovio (BASF), Mater Bi (Novamont), PLA (Nature Works) and Cellophane were also tested in compost as reference.

Visual appearance of polyolefin films did not significantly change after composting,although the biodegradable films fell apart or disappeared. Only some pieces of cellophane film could be collected for testing.

The change in thickness of polyolefin films in compost was not significant, however an increase was observable on Cellophane film, which may be due to biofilm formation.

Tensile strength decreased significantly in case of commercial MDPE and of the biodegradable cellophane. Some polyolefins showed a slight increase in tensile strength, which may be due to cross-linking as a result of initial degradation. Elongation at break did not change significantly for polyolefin films, it drastically decreased however for the biodegradable ones. It may be concluded, that only the biodegradable films have been mechanically detered in the compost.
FTIR-spectra showed increase in oxo-group absorption in polyolefin films after composting due to oxidation. Other structural changes were not detectable. Degradable films however showed drastic changes in structure after composting due to oxidation.

ESR-spectra of degradable films indicated the appearance of free radicals after composting. Free radicals could be detected in Zöld híd film (MDPE with pro-oxidants) after a week exposure to sunlight, and concentration of free radicals increased after composting. Presence of free radicals were not detected after composting in polyolefin films without exposure to sunlight.

All polyolefin films showed slight decrease in number-average molecular mass, and an increase in polydispersity, which may refer to a small extent of degradation. SEM images supported that commercial polypropylene crystallized during composting, however microorganisms could not be detected on PP surface. LDPE did not crystallize during composting, although no microorganisms appeared on its surface. Noteworthy is however that a great coverage of microorganisms appeared on the surface of commercial MDPE film after composting. In case of HDPE composting resulted only a few microorganisms. The pro-oxydant containing MDPE namely Zöld híd film had fewer microorganism than the commercial MDPE film. The pro-oxidant containing MDPE films PE238 and PE242 behave similarly to Zöld Híd film, practically no microorganisms could be detected on their surface after composting. The pro-oxidant and TPS containing MDPE films PE264 and PE297 were somewhat more suscaptable for microorganism during composting than the films without TPS. The surface of the biodegradable films, BASF, Mater Bi, Cellophane and PLA were 
fully covered with microorganisms of different types and threads of fungi formed on their surface in compost. Based on the results of SEM it may be concluded that commercial PP, LDPE and HDPE have no affinity to microorganisms in compost. Surprisingly commercial MDPE was susceptible for microbial attack. Pro-oxidant containing MDPE was less susceptible for microorganisms as though pro-oxidant would repel microbes. Even the presence of thermoplastic starch did not attract more microbes in the compost, meaning that the TPS containing films had less microorganisms on their surface than the commercial MDPE.

On the base of our life-like experiments it can be concluded that polyolefin films neither degrade in compost nor undergo biodegradation.

\section{ACKNOWLEDGEMENTS}

Authors thank the National Development Agency (NFÜ) Tech09-BDREVAM-2, TÁMOP-4.2.1B-11/2/ KMR-2011-0003 and the Faculty Support of Excellence Research Centre of Excellence- 17586-4/2013/ TUDPOL. Authors are thankful to Plastics Processing Plant Tázlár for film-blowing.

\section{SUMMARY}

Signs of initial degradation were observable on MDPE films with pro-oxidative additives and TPS after 6 week composting, although it is not biological degradation. Non of the tested polyolefin films suffered such degree of degradation in compost, as the biologically degradable ones.

Number-average molecular mass decreased in all polyolefinfilms, and polydispersity has increased. This refers to initial degradation.

Presence of microorganisms could be detected by SEM on commercial polyolefin films after composting. However signs of degradation (pores or holes) could not be found.

The biodegradable films showed much more microorganisms on their surface after composting than the polyolefin films, and of different types and shape. There were also pores and holes on their surface as signs of bio-deterioration.

MDPE films with pro-oxidative additives (PE238, PE242) contained less microorganisms on their surface after composting, than the commercial films. Films containing TPS (PE264, PE297) had a little bit more microorganisms than films with only pro-oxidative additives. This may suggest that these additives repel, while the presence of TPS in the films somewhat attracts the microorganisms.

\section{REFERENCES}

[1] https://issuu.com/plasticseuropeebook/docs/final_plastics_th e_facts_2014_19122 22.02.2016

[2] Albertsson AC, Andersson SO, Karlsson S. The mechanism of biodegradation of polyethylene. Polym Degrad Stab 1987; 18: $73-87$

http://dx.doi.org/10.1016/0141-3910(87)90084-X

[3] Albertsson AC, Karlsson S. The influence of biotic and abiotic environments on the degradation of polyethylene. Prog Polym Sci 1990; 15: 177-92.

http://dx.doi.org/10.1016/0079-6700(90)90027-X

[4] Albertsson A-C, Erlandsson B, Hakkarainen M, Karlsson S. Molecular weight changes and polymeric matrix changes correlated with the formation of degradation products in biodegraded polyethylene. J Polym Environ 1998; 6: 187-95. http://dx.doi.org/10.1023/A:1021873631162

[5] Albertsson AC, Banhidi ZG. Microbial and oxidative effects in degradation of polyethene. J Appl Polym Sci 1980; 25: 165571.

http://dx.doi.org/10.1002/app.1980.070250813

[6] Albertsson AC, Barenstedt C, Karlsson CS. Abiotic degradation products from enhanced environmentally degradable polyethylene. Acta Polym 1993; 45: 97-103. http://dx.doi.org/10.1002/actp.1994.010450207

[7] Albertsson AC, Barenstedt C, Karlsson S, Lindberg T. Degradation product pattern and morphology changes as means to differentiate abiotically and biotically aged degradable polyethylene. Polymer 1995; 36: 3075-83. http://dx.doi.org/10.1016/0032-3861(95)97868-G

[8] Albertsson AC, Barenstedt C, Karlsson S. Solid-phase extraction and gas chromatographic-mass-spectrometric identification of degradation products from enhanced environmentally degradable polyethylene. J Chromat A 1995; 690: 207-17. http://dx.doi.org/10.1016/0021-9673(94)01016-8

[9] Koutny M, Lemaire J, Delort AM. Biodegradation of polyethylene films with prooxidant additives. Chemosphere 2006; 64: 1243-52.

http://dx.doi.org/10.1016/j.chemosphere.2005.12.060

[10] Shah AA, Hasan F, Hameed A, Ahmed S. Biological degradation of plastics: A comprehensive review. Biotechnol Adv 2008; 26: 246-65. http://dx.doi.org/10.1016/j.biotechadv.2007.12.005

[11] Bienaime LN, Belloy C, Queneudec M, Silvestre F, NavaSaucedo JE. Polymer biodegradation: Mechanisms and estimation techniques. Chemosphere 2008; 73: 429-42. http://dx.doi.org/10.1016/j.chemosphere.2008.06.064

[12] Eubeler JP, Bernhard M, Zok S, Knepper TP. Environmental biodegradation of synthetic polymers I. Test methodologies and procedures. Trends Anal Chem 2009; 28: 1057-72. http://dx.doi.org/10.1016/j.trac.2009.06.007

[13] Eubeler JP, Bernhard M, Thomas P, Knepper TP. Environmental biodegradation of synthetic polymers II. Biodegradation of different polymer groups. Trends Anal Chem 2010; 29: 84-100.

http://dx.doi.org/10.1016/j.trac.2009.09.005

[14] Kyrikou I, Demetres Briassoulis C. Biodegradation of agricultural plastic films: a critical review. J Polym Environ 2007; 15: 125-50.

http://dx.doi.org/10.1007/s10924-007-0053-8

[15] Feuilloley P, Ce'sar G, Benguigui L, et al. Degradation of polyethylene designed for agricultural purposes. J Polym Environ 2005; 13: 349-55.

http://dx.doi.org/10.1007/s10924-005-5529-9 
[16] Fontanella S, Bonhomme S, Koutny M, et al. Comparison of the biodegradability of various polyethylene films containing pro-oxidant additives. Polym Degrad Stability 2010; 95: 1011-21.

http://dx.doi.org/10.1016/j.polymdegradstab.2010.03.009

[17] Corti A, Muniyasamy S, Vitali M, Imam SH, Chiellini E. Oxidation and biodegradation of polyethylene films containing pro-oxidant additives: Synergistic effects of sunlight exposure, thermal aging and fungal biodegradation. Polym Degrad Stability 2010; 95: 1106-114. http://dx.doi.org/10.1016/j.polymdegradstab.2010.02.018

[18] Soni E, Anil Ć, Kapri CM, Zaidi GH, Goel ĆR. Comparative biodegradation studies of non-poronized and poronized LDPE using indigenous microbial consortium. J Polym Environ 2009; 17: 233-9. http://dx.doi.org/10.1007/s10924-009-0143-x

[19] Siracusa V, Rocculi P, Romani S, Dalla Rosa M. Biodegradable polymers for food packaging: a review. Trends Food Sci Technol 2008; 19: 634-43. http://dx.doi.org/10.1016/j.tifs.2008.07.003

[20] Muthukumar T, Aravinthan A, Mukesh D. Effect of environment on the degradation of starch and pro-oxidant blended polyolefins. Polym Degrad Stability 2010; 95: 1988993.

http://dx.doi.org/10.1016/j.polymdegradstab.2010.07.017

[21] Huang CY, Roan ML, Kuo MC, Lu WL. Effect of compatibiliser on the biodegradation and mechanical properties of high-content starch/low-density polyethylene blends. Polym Degrad Stability 2005; 90: 95-105. http://dx.doi.org/10.1016/j.polymdegradstab.2005.02.015

[22] Nakamura EM, Cordi L, Almeida GSG, Duran N, Mei LHI. Study and development of LDPE/starch partially biodegradable compounds. J Mater Proc Technol 2005; 162163: 236-41.

http://dx.doi.org/10.1016/j.jmatprotec.2005.02.007

[23] Thakore IM, Desai S, Sarawade BD, Devi S. Studies on biodegradability, morphology and thermomechanical properties of LDPE/modified starch blends. Eur Polym J 2001; 37: 151-60.

http://dx.doi.org/10.1016/S0014-3057(00)00086-0

[24] Zuchowska D, Hlavatá D, Steller R, Adamiak W, Meissner W. Physical structure of polyolefin/starch blends after ageing. Polym Degrad Stability 1999; 64: 339-46. http://dx.doi.org/10.1016/S0141-3910(98)00212-2
[25] Zuchowska D, Steller R, Meissner W. Structure and properties of degradable polyolefin-starch blends. Polym Degrad Stability 1998; 60: 471-80. http://dx.doi.org/10.1016/S0141-3910(97)00110-9

[26] Dave H, Rao PVC, Desai JD. Biodegradation of starchpolyethylene films in soil and by microbial cultures. World $\mathrm{J}$ Microbiol Biotechnol 1997; 13: 655-8.

http://dx.doi.org/10.1023/A:1018566820659

[27] Chandra R, Rustgi R. Biodegradation of maleated linear lowdensity polyethylene and starch blends. Polym Degrad Stability 1997; 56: 185-202. http://dx.doi.org/10.1016/S0141-3910(96)00212-1

[28] Contat-Rodrigo L, Ribes-Greus A. Mechanical behaviour of biodegradable polyolefins. J Non-Crystalline Solids 1998; 235-237: 670-6. http://dx.doi.org/10.1016/S0022-3093(98)00618-8

[29] Abd El-Rehim HA, Hegazy EA, Ali AM, Rabie AM. Synergistic effect of combining UV-sunlight-soil burial treatment on the biodegradation rate of LDPE/starch blends. J Photochem Photobiol A Chem 2004; 163: 547-56. http://dx.doi.org/10.1016/j.jphotochem.2004.02.003

[30] Ojeda TFM, Dalmolin E, Forte MMC, Jacques RJS, Bento FM, Camargo FAO. Abiotic and biotic degradation of oxobiodegradable polyethylenes. Polym Degrad Stability 2009; 94: 965-70.

http://dx.doi.org/10.1016/j.polymdegradstab.2009.03.011

[31] Chiellini E, Cortia A, Swift A. Biodegradation of thermallyoxidized, fragmented low-density polyethylenes. Polym Degrad Stability 2003; 81: 341-51. http://dx.doi.org/10.1016/S0141-3910(03)00105-8

[32] Matsunaga M, Whitney PJ. Surface changes brought about by corona discharge treatment of polyethylene film and the effect on subsequent microbial colonisation. Polym Degrad Stability 2000; 70: 325-32. http://dx.doi.org/10.1016/S0141-3910(00)00105-1

[33] Kaur I, Gupta N, Kumari V. Swelling, ion uptake and biodegradation studies of PE film modified through radiation induced graft copolymerization. Rad Phys Chem 2012; 81: 947-56.

[34] Epstein E. The science of compostingn Technomic Publishing Co. 1997 p-487 ISBN 1-56676-478-5

[35] Vargha V, Rétháti $G$, Heffner $T$, et al. Behavior of polyethylene films in soil. Periodica Polytech Chem Eng 2016; 60: 60-8. http://dx.doi.org/10.3311/PPch.8281 